\title{
Derleme
}

\section{Çocuklardaki dış kaynaklı diş renklenmelerinde kromojenik bakterilerin rolü}

\author{
Zuhal Kırzıoğlu, Burcu Güçyetmez Topal* \\ Pedodonti Anabilim Dalı, Diş Hekimliği Fakültesi, Süleyman \\ Demirel Üniversitesi, Isparta, Türkiye
}

\begin{abstract}
Özet
Diş renklenmeleri, çocuklarda sosyal ve psikolojik sorunlara yol açarak özgüven kayıplarına sebep olabilmektedir. Ebeveynlerinin ve çocukların dış görünüşleriyle ilgili kaygıları ve estetik arayışları, günümüzde diş hekimliğinde çocuklardaki estetik tedavinin önemini arttırmaktadır. Çocuklarda dış kaynaklı diş renklenmeleri hem süt hem de daimi dişlenmede görülebilmektedir. Dış kaynaklı renklenmelerin etiyolojisinde kötü ağız hijyeni, demir preparatlarının kullanımı ve kromojenik bakteriler yer almaktadır. Kromojenik bakteriler, çocuklarda diş yüzeyinde siyah/ kahverengi, yeşil, turuncu veya mavi gibi renklenmeler oluşturabilmektedir. Çocuklarda görülen dış kaynaklı diş renklenmeleri arasında, klinisyenlerin en çok ilgisini çeken, daha sık karşılaşılan siyah renklenmeler olmuştur ve araştırmaların birçoğu buna yol açan kromojenik bakteriler üzerine yoğunlaşırken, diğer renklenmelerle ilgili veriler sınırı kalmıştır. Gelişen mikrobiyolojik tanı yöntemleriyle, mevcut kromojenik bakterilerin mekanizmaları hakkındaki bilgilerimiz artmakta ve renklenmeye neden olan yeni bakteriler tespit edilebilmektedir. Ancak, ulaşılabilir kaynaklarda kromojenik bakterilerin renklenmeye yol açan mekanizmalarıyla ilgili çalışmalar yetersiz kalmıştır. Bu makalede, çocuklardaki dış kaynaklı diş renklenmelerinde kromojenik bakterilerin rolünün vurgulanması, bu renklenmelerin tedavilerinin ve alınabilecek önlemlerin gözden geçirilmesi ve klinisyenlerin bu konudaki mevcut bilgilerine katkı sağlanması amaçlanmaktadır.
\end{abstract}

Anahtar Kelimeler: Ağız hijyeni; dişte renk değişikliği; süt dişi

KaynaK GöstermeK İçiN: Kırzıoğlu Z, Güçyetmez Topal B. Çocuklardaki dış kaynaklı diş renklenmelerinde kromojenik bakterilerin rolü. Acta Odontol Turc 2016;33(3):161-5

EDiтör: Neşe Akal, Gazi Üniversitesi, Ankara, Türkiye

YAYıN HAKKI: @ 2016 Kırzıoğlu ve Güçyetmez Topal. Bu eserin yayın hakkı Creative Commons Attribution License ile ruhsatlandırımıştır. Sınırsız kullanım, dağıtım ve her türlü

Makale gönderiliş tarihi: 04 Ekim 2015; Yayına kabul tarihi: 09 Aralık 2015 *iletişim: Burcu Gücyetmez Topal, Süleyman Demirel Üniversitesi, Diş Hekimliği Fakültesi, Pedodonti Anabilim Dalı, Isparta, Türkiye;

E-posta: dt.burcugucyetmez@ hotmail.com ortamda çoğaltım, yazarlar ve kaynağın belirtilmesi kaydıyla serbesttir.

[Abstract in English is at the end of the manuscript]

\section{Giriş}

Diş renklenmeleri çocuklar ve adolesanların sosyal yaşantısını ve psikolojisini etkileyerek, özgüven kaybına yol açabilmektedir. Genetik, çevresel, bakteriyel, medikal ve dişe ait çeşitli faktörlerle meydana gelen diş renklenmeleri, geçmişten bugüne birçok araştırmacının ilgisini çekmiştir. Sosyal çevrelerde reklamların etkisiyle görselliğin ön planda olması, dolayısıyla ebeveynlerin estetiğe ilgilerinin artması ve çocukların dış görünüşleri ile ilgili kaygıları günümüzde diş hekimliğinde çocuklardaki diş renklenmelerinin estetik tedavisinin önemini artırmaktadır.

Çocuklarda hem süt hem de daimi dişlenmede görülen dış kaynaklı renklenmelerin etiyolojisinde kötü ağız hijyeni, demir preparatlarının kullanımı ve kromojenik bakteriler ön plandadır. ${ }^{1}$ Diş yüzeyinde görülme sıklıklarına göre siyah/kahverengi, yeşil, turuncu, mavi gibi çeşitli renklenmeler yapabilen kromojenik bakterilerin neler olduğu ile ilgili çalışmalar yapılmıştır, ancak renklenmeye yol açan mekanizmaları tam anlamıla aydınlatılamamıştır. ${ }^{2}$

Çocuklardaki dış kaynaklı diş renklenmelerinde kromojenik bakterilerin rolünün vurgulanması ve ulaşılabilir kaynaklardan elde edilen bilgiler ışığında bu konudaki mevcut bilgilerin hatırlatılması, klinisyenlerin farkındalıklarının arttırılması açısından önem arz etmektedir.

\section{Siyah renklenmeler}

Çocuklarda görülen dış kaynaklı diş renklenmeleri arasında, araştırmacıların en çok ilgisini çeken siyah renklenmelerin görülme sıklığı ile ilgili birçok ülkede çalışmalar yapılmış ve \%3.1 ile \%18 arasında deği-

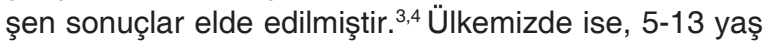
arasındaki çocuklarda siyah renklenme görülme sıklığı \%17 olarak belirtilmiştir. ${ }^{4}$

Siyah renklenmeler, süt ve daimi dişlerde dişeti kenarına paralel seyreden noktasal, ince çizgi ya da geniş bant şeklinde görülen renklenmelerdir. ${ }^{4-8}$ Kahve- 


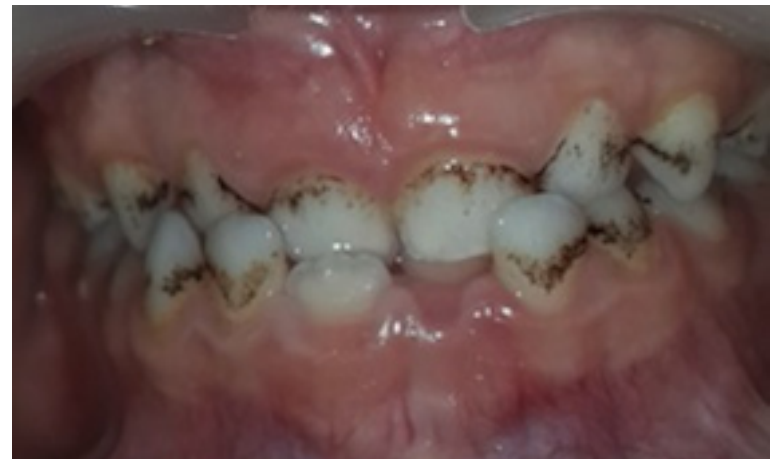

Resim 1. Kliniğimize başvuran, kapanış bozukluğu olan 6 yaşındaki hastamızda görülen dış kaynaklı siyah renklenmeler

rengiden antrasit-siyaha doğru giden renk yoğunluğu gösterebilirler (Resim1). ${ }^{2}$ Tükürüğün yıkayıcı etkisinden daha az yararlanan üst çene ön dişlerde, bakterilerin adezyonunun ve kolonizasyonun kolay olması sonucu sık görülmektedirler. ${ }^{4} \mathrm{Bu}$ renklenmeler genellikle oral hijyeni iyi, çürük görülme sıklığı düşük olan çocuklarda tespit edilmiştir. ${ }^{2-8}$

Siyah renkli materyal, ferrik sülfid benzeri bir bileşiktir ve bakterilerin ürettiği hidrojen sülfid ile tükürük ya da dişeti sıvısında bulunan demirin etkileşimi sonucu oluşmaktadır. Siyah renklenme, çözünmeyen demir tuzları ve yüksek kalsiyum ve fosfat içermesiyle diğer dental plak formlarından ayrılmaktadır. ${ }^{5}$ Plakta, karakteristik olarak Actinomyces, Prevotella ve Porphyromonas türleri baskın olarak bulunmuştur. ${ }^{2}$ Streptococcus grubu bakterilerin ise florada yaklaşık \%5 oranında bulunduğu belirtilmiştir. ${ }^{6}$

\section{Actinomyces grubu bakteriler}

Siyah renklenme görülen çocuklarda yapılan Polimeraz Zincir Reaksiyonu (PZR) analizi sonucu, Actinomyces'in baskın mikroorganizma olduğu bildirilmiştir. ${ }^{1}$ Bir diğer çalışmada immünolojik araştırmalar sonucu, siyah renklenme varlığında biyofilm tabakasında Actinomyces naes/undii'nin baskın olduğu görülmüştür. ${ }^{9}$ Ayrıca, Actinomyces türlerinden Actinomyces odontolyticus, Actinomyces radicidentis, Actinomyces graevenitzii ve Actinomyces urogenitalis'in de kırmızıdan siyaha değişen pigmentler ürettikleri rapor edilmiştir. ${ }^{10}$

Actinomyces, insan ve hayvan muköz membranlarında oluşan ilk bakterilerdendir. Bunlar gram pozitif, aside dirençli, fakültatif anaerob veya zorunlu anaerob, ekstrasellüler yerleşimli sporsuz basillerdir. Kolonilerinde in vivo sülfür granülleri oluşturur ve birçok besiyerinde anaerob şartlarda yavaş ürerler. ${ }^{11}$

Bebeklerin ağzında ilk olarak izole edilebilen bakterilerden olan Actinomyces'lerin en önemli özellikleri doku üzerine yapışması ve diğer bakterilerle birleşebilmesidir. Bu nedenle plak oluşumunun başlangıcından da sorumlu tutulmaktadır. ${ }^{12}$

Actinomyces'ler, tükürük ve dişeti oluğu sıvısındaki bazı komponentlerden enerji üretmek ve çoğalmak için gerekli enzimlere sahiptirler. Bu enzimlerin reaksiyonu sonucu açığa çıkan amonyak, plak pH'sinin artması- na ve bu bölgeye daha az karyojenik olan bakterilerin (Streptococcus salivarius) tutunup, çoğalmasına neden olurlar. Ayrıca, bu mikroorganizmaların çürük oluşumunu azalttığı ve diş taşı oluşumunu da dolaylı olarak arttırdığı düşünülmektedir. ${ }^{4}$

\section{Prevotella grubu bakteriler}

Oral kavitede yerleşim gösteren, anaerob, gram negatif, çomak şekilli olan Prevotella grubunun renklenme yapan en önemli türlerinden Prevotella melaninogenica diğer siyah pigmentli bakterilerden indol testine pozitif yanıt vermesi ile ayrılabilmektedir. Önceki yıllarda tek tür olarak düşünülen ve 1990'lı yıllarda yeniden sınıflandırılan Prevotella intermedia ve Prevotella nigrescens de siyah renklenmeden en çok sorumlu tutulan mikroorganizmalar arasındadır. ${ }^{13}$

$\mathrm{Bu}$ organizmalar hemoglobine bağlanırlar ve eksternal demiri üretmeleri için kaynak olarak hemoglobini kullanırlar. ${ }^{14} P$. nigrescens'in hemoglobin bağlayan özel yüzey proteinleri bulunmaktadır. $P$. intermedia ise hemoglobini heme indirgeyerek, büyümesi için gerekli olan demiri açığa çıkarır. Oksihemoglobin ilk olarak $P$. intermedia ve $P$. nigrescens varlığında (Fe(III)PPIX) ${ }_{2}$ 'ye dönüşür, daha sonra da $\mathrm{pH}$ 'nin düşmesiyle yüzey hücrelerinde çözünmeyen Fe(III)PPIX.OH oluşmaktadır. ${ }^{15}$ Bu mekanizma, diş yüzeyinde görülen siyah materyallerin oluşumunu açıklayabilmektedir.

Prevotella türleri, süt ve daimi dişlerde siyah renklenmeye yol açmaktadır. Yaygın siyah renklenme görülen 2 yaşındaki çocuk hastada yapılan bakteriyel DNA analizi sonucu, bu bakterilerin baskın mikroorganizma olduğu rapor edilmiştir. ${ }^{7}$

$P$. intermedia için primer yaşam alanı dişeti oluğudur ve bu bakteri çeşitli periodontal hastalıklarla ve ağız kokusuyla da ilişkili bulunmuştur. ${ }^{16} P$. nigrescens ise fırsatçı bir patojendir, sağlıklı dokularda tespit edilmesine rağmen, endodontik enfeksiyon ve hafif-orta şiddette periodontitiste de rol oynamaktadır. ${ }^{17}$

\section{Porphyromonas gingivalis}

Siyah renklenmelerden sorumlu tutulan bakterilerden olan $P$. gingivalis'in hastalık yapabilmesi için, hemine intiyacı vardır. Bu bakterilerin renklenmeye yol açan mekanizması, Prevotella türü ile benzer şekilde hem varlığında ferrik sülfid benzeri bileşik oluşmasıyla gerçekleşmektedir. ${ }^{4}$

Genel olarak hareketsiz çomak şeklinde olan $P$. gingivalis'in majör kolonizasyon bölgesi dişeti cebidir, dil ve tonsillerden de izole edilebilmektedir. İnsanda ve deney hayvanlarında periodontal yıkım yapmaları nedeni ile agresif periodontal patojen olarak da kabul edilirler. ${ }^{18}$

\section{Yeşil renklenmeler}

Yeşil renklenmeler, genellikle üst çene süt kesici dişlerin dudak yüzeyinde kolenin 1/3'ünü kaplayan kalın, sıkıca yapışmış bant şeklindeki oluşumlardır. Griden, kahve- 


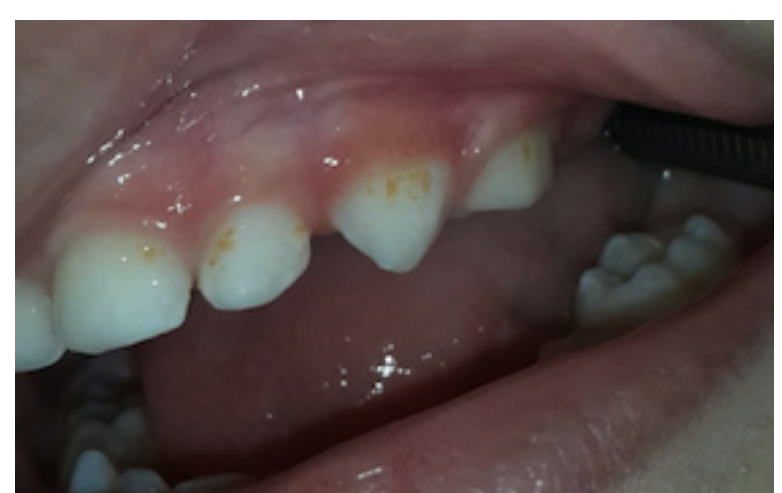

Resim 2. Kliniğimize başvuran 3 yaşındaki hastamızda görülen turuncu-sarı renklenmeler

rengi-yeşile kadar değişen renk yelpazesine sahip bu renklenmeler, erkeklerde kızlara oranla iki kat daha fazla görülmektedir. ${ }^{19} \mathrm{Bu}$ renklenmenin kimyasal bileşenleri arasında ise alüminyum, baryum, nikel, bakır, bor, stronsiyum ve potasyum bulunmaktadır. ${ }^{2}$ Çocuklardaki bu boyanmanın sebebi, dişlerin sürmeleri esnasında diş yüzeylerinde mevcut olan Nasmyth zarının zamanla parçalanarak diş yüzeyinden tamamen uzaklaşamaması, kromojenik materyallerin ve bakterilerin eklenmesi sonucu boyanmasıdır. ${ }^{4}$ Bakteriyel hidrojen sülfid de bu renklenmelerden sorumlu tutulmaktadır. ${ }^{2}$

Dış kaynaklı yeşil renklenmelerden Pseudomonas aeruginosa gibi floresan bakterilerin yanı sıra, Penicillium glaucum ve Aspergillus gibi mantarlar da sorumlu tutulmaktadır. Mantarların büyümek için ışığa ihtiyaç duymaları ve bu renklenmelerin de ışık gören ön dişlerde sık oluşması bu görüşü desteklemektedir. ${ }^{2,4,20}$

\section{Pseudomonas aeruginosa}

P. aeruginosa, mavi-yeşil renkli 'piyosiyanin' pigmenti üretmektedir ve çocuklardaki yeşil ve mavi renklenmelerden bu pigmentin sorumlu olabileceği belirtilmektedir. ${ }^{21,22} P$. aeruginosa aerobik, gram negatif ve hareketli çubuk şekilli bakteridir. Kendi gelişmeleri için gerekli faktörleri ve vitaminleri sentezleme yeteneğindedirler. ${ }^{22}$ Bakteri özellikle, bağışıklık yetersizliği olan hastalarda solunum ve idrar yollarının, yanıkların ve açık yaraların fırsatçı patojenidir, aynı zamanda kanda da enfeksiyonlar yapabilir.

\section{Turuncu-sarı renklenmeler}

Siyah ve yeşil renklenmelere oranla daha az sıklıkta görülen turuncu renklenmeye, kesici dişlerin dudak yüzeyinin diş etine yakın bölgesinde rastlanılmaktadır. (Resim 2) Kolede dişeti kenarında düzenli sınırları vardır, kesici kenara doğru renklenme gittikçe kaybolur ve belirli bir kalınlıkları yoktur. En çok renklenme orta kesici dişlerde olup, köpek dişlerine doğru azalmaktadır. Genellikle ağız hijyeni kötü olan çocuklarda görülmektedir, bununla birlikte gelişimsel ve beslenme bozukluğu olan çocuklarda da görülebilmektedir. ${ }^{4}$ Bu renklenmeler, diş yüzeyinden kolaylıkla kaldırılabilir ancak tekrar etmektedirler.
Turuncu-sarı renklenme yapan bakteriler Serratia marcescens, Flavobacterium lutescens ve Micrococcus roseus olarak bildirilmiştir. ${ }^{23} \mathrm{Bu}$ bakterilerin yanı sıra, Sarcina rosea, Bacillus roseus, Bacillus rouge de kiel, Bacillus prodigieus da turuncu-sarı renklenmelerden sorumlu tutulan bakteriler arasında yer almaktadır. 2,20,23

\section{Serratia marcescens}

S. marcescens, çocuklarda subgingival biyofilm tabakasına yerleşebilmektedir ve diş yüzeyinde renklenmelere yol açan 'prodigiosin' adı verilen turuncu-kırmızı bir pigment üretmektedir. Prodiogiosin üretiminin biyokimyasal yolu tam olarak bilinmemektedir, ancak, monopirol (MAD) ve bipirol (MPC) enzimlerinin yoğunlaşma reaksiyonu sonucu oluştuğu düşünülmektedir. ${ }^{24}$

Enterobacteriacae ailesinden olan gram negatif, hareketli çubuk şeklindeki bu bakteriler, çocuklarda gastrointestinal sisteme yerleşmektedir. S. marcescens özellikle hastane enfeksiyonlarında, üriner sistem ve yara enfeksiyonlarında yaygın olarak görülmektedir. ${ }^{25}$

\section{Flavobacterium lutescens}

F. lutescens'in, diş yüzeyinde sarı, sarı-turuncu renklenme oluşturduğu bildirilmiştir, ancak mekanizmaları henüz açıklanamamıştır. ${ }^{23,26}$ Doğal yaşam alanı su olan bu bakteriler, gram negatif, hareketsiz, sporsuz çubuk şeklinde bakterilerdir. Aerob veya fakültatif anaerob olabilirler. ${ }^{27}$

\section{Micrococcus roseus}

Adını ürettiği karotenoid salgıdan alan $M$. roseus'un, diş yüzeyinde turuncu renklenmelere yol açtığı düşünülmektedir. ${ }^{2} \mathrm{Bu}$ bakteri, gram pozitif zorunlu aerob bakterilerdendir. ${ }^{28}$

\section{Mavi renklenmeler}

Çocuklarda çok nadir de olsa dış kaynaklı mavi diş renklenmelerine de rastlanılmaktadır. Bussell \& Deerey ${ }^{22}$, West sendromlu, perkütan endoskopik gastrostomi tüpü ile beslenen 4 yaşındaki çocuk hastanın diş yüzeyinde koyu mavi renklenmeler oluştuğunu bildirmişlerdir. Yapılan tetkikler sonucu, diş yüzeyinde $P$. aeruginosa'nın baskın olduğunu ve mavi renklenmelerin bu bakteri kaynaklı olabileceğini rapor etmişlerdir.

Çocuklarda karşılaşılabilen dış kaynaklı diş renklenmeleri ve sorumlu mikroorganizmalar Tablo 1'de özetlenmiştir.

Tablo 1. Çocuklarda görülen dış kaynaklı kromojenik diş renklenmeleri ve sorumlu mikroorganizmalar

\begin{tabular}{ll}
\hline Renklenme & Mikroorganizma \\
\hline Siyah (Kahverengi) & $\begin{array}{l}\text { A. naeslundii, P. melaninogenica, P. intermedia, } \\
\text { P. nigrescens, P. gingivalis }\end{array}$ \\
Yeşil & P. aeruginosa, P. glaucum, Aspergillus \\
Turuncu-sarı & $\begin{array}{l}\text { S. marcescens, F. lutescens, M. roseus, S. rosea, } \\
\text { Mavi }\end{array}$ \\
\hline
\end{tabular}




\section{Kromojenik bakteri kaynaklı diş renklenmelerinin tedavileri ve alınabilecek önlemler}

Ebeveynlerin klinisyenlere en çok başvurduğu renklenmeler genellikle süt dişlerinde görülen siyah renklenmelerdir. Bu renklenmelere yol açan kromojenik bakterilerin birçoğu demir varlığında büyüdüğü için, demir preparatı kullanan çocuklarda renklenme olasılığı artmaktadır. ${ }^{29} \mathrm{Bu}$ ilaçların kullanımı sonrası, heme intiyaç duyan kromojenik bakterilerin kolonizasyonunu azaltabilmek için, ağzın su ile çalkalatılması ve diş yüzeylerinin temizlenmesi gerekmektedir.

Yapılan çalışmalarda, kromojenik bakterilerden siyah renklenmeye yol açan $P$. intermedia ve $P$. nigrescensin çocuğa, ebeveynlerinden veya kardeşlerinden kolaylıkla geçiş yapabileceği bildirilmiştir. ${ }^{30,31}$ Bu sonuç doğrultusunda; tabak, kaşık, çatalların ve diş fırçalarının ortak kullanımı, emzik veya biberon başIıklarının tükürük ile temizlenmesi, çocuğun dudaktan öpülmesi gibi aile içi bakteri geçişine yol açabilecek alışkanlıklar engellenmeli, ebeveynler kendi oral hijyenleri konusunda dikkatli olmalıdır.

Kromojenik bakteri kaynaklı renklenmelerden turuncu ve yeşil renklenmeler, genellikle oral hijyeni kötü olan çocuklarda görülmektedir. ${ }^{5} \mathrm{Bu}$ hastalarda iyi bir oral hijyen eğitimi verilerek hastaların bilinçlendirilmesi, etkili ve düzenli diş fırçalama alışkanlığı kazandırıması bu renklenmelerin giderilmesi ve yeni renklenmelerin önlenebilmesi için en önemli ve en kolay yöntemdir.

Çocuklardaki dış kaynaklı diş renklenmelerinin tedavileri için genellikle polisaj işlemi yeterli olmaktadır. Ultrasonik ve sonik temizleyiciler renklenmelerin giderilmesinde zaman ve güç tasarrufu sağlamaktadır ancak çocuklardaki kullanımı sırasında dikkatli olunmalıdır. ${ }^{5}$

Polisaj işlemleri sırasında açığa çıkan ısının, özellikle pulpası geniş olan süt dişlerinde pulpa nekrozunu başlatabildiği ve minenin floridden zengin dış tabakasının polisaj ile uzaklaştırıldığı bildirilmiştir. ${ }^{32} \mathrm{Bu}$ durum özellikle yüksek çürük aktivitesi olan çocuklarda daha da önemli hale gelmektedir. Dolayısıyla bu hastalarda çok gerekli olmadıkça polisaj işleminden kaçınılmalı, tedavi gereksinimi dikkatli değerlendirilmelidir. Polisaj ile uzaklaştırılan floridi bir miktar yerine koyabilmek için florid içeren pat kullanılması önerilmiş ancak yapılan çalışmalarda topikal florid kullanımının daha etkili olduğu bildirilmiştir. ${ }^{33}$

Günümüzde PZR ile yapılan biofilm analizleri ümit verici çalışmalar olarak görülmekte, bu yöntemle çocukların ağız içi bakterileri tanımlanabilmektedir. ${ }^{8}$ Çocuklarda görülen kromojenik bakteri kaynaklı diş renklenmeleri ile ilgili ileride yapılacak çalışmaların arttırılması ile, hem klinisyenlerin gereksiz zaman kaybı önlenecek hem de tekrarlayan tedavi masraflarının önüne geçilmiş olunacaktır.

\section{SonUÇ}

Çocuklardaki dış kaynaklı renklenmelerin en sık se- beplerinden biri kromojenik bakterilerdir. Gelişen mikrobiyolojik tanı yöntemleriyle, renklenmeye neden olan yeni bakteriler tespit edilebilmekte ve mevcut bakterilerin mekanizmaları hakkındaki bilgilerimiz artmaktadır. Ancak, ulaşılabilir kaynaklarda kromojenik bakterilerin renklenmeye yol açan mekanizmalarıyla ilgili çalışmalar yeterli değildir. Araştırmaların birçoğu daha sık karşılaşılan siyah renklenmeler ve buna yol açan kromojenik bakteriler üzerine yoğunlaşırken, diğer renklenmelerle ilgili veriler sınırı kalmıştır. Kromojenik bakteriler ile igili çalışmalara ağırlık verilmesi ile çocuklarda karşılaşılan bakteriyel dış kaynaklı renklenmelerin önüne geçilebilmesi konusunda klinisyenlere yeni ufuklar açılacaktır.

Çıkar çatışması: Yazarlar bu çalışmayla ilgili herhangi bir çıkar çatışmalarının bulunmadığını bildirmişlerdir.

\section{KAYNAKLAR}

1. Saba C, Solidani M, Berlutti F. Black stains in the mixed dentition: A PCR microbiological study of the etiopathogenic bacteria. J Clin Pediatr Dent 2006;30:219-24.

2. Schuurs A. Pathology of the dental hard tissues. 1st edn. Chichester, West Sussex, UK: Wiley Blackwell; 2013. p. 245-8.

3. Martin G, Manuel J, Gonzalez Garcia M, Seoane Leston J, Llorente Pendas S, Diaz Martin JJ, et al. Prevalence of black stain and associated risk factors in preschool Spanish children. Pediatr Int 2013;55:355-9.

4. Garan A. 6-12 yaş grubu çocuklarda kromojen bakterilere bağlı siyah dışsal renklenmelerin biyokimyasal ve mikrobiyolojik olarak incelenmesi [tez]. İstanbul: Marmara Üniversitesi; 2009.

5. Prathap S, Rajesh H, Boloor VA, Rao AS. Extrinsic stains and management: a new insight. J Acad Indus Res 2013;1:432-5.

6. Slots J. The microflora of black stain on human primary teeth. Scand J Dent Res 1974;82:484-90.

7. Takashima Y, Matsumi Y, Yamasaki Y, Hirano K, Yanagida K, Fujita $\mathrm{K}$, et al. Black pigmentation in primary dentition: Case report and literature review. Pediatr Dent J 2014;24:184-8.

8. Costa MT, Dorta ML, Pimenta FC. Biofilms of black tooth stains: PCR analysis reveals presence of Streptococcus mutans. Braz Dent J 2012;23:555-8.

9. Stenudd C, Nordlund A, Ryberg M, Johansson I, Kallestal C, Stromberg $\mathrm{N}$. The association of bacterial adhesion with dental caries. J Dent Res 2001;80:2005-10.

10. Sarkonen N, Kononen E, Summanen P, Kononen M, JousimiesSomer H. Phenotypic identification of Actinomyces and related species isolated from human sources. J Clin Microbiol 2001;39:3955-61.

11. Hall V, Collins MD, Lawson PA, Falsen E, Duerden B. Actinomyces dentalis spp. nov. from human dental abscess. Indian J Sleep Med 2005;55:427-31.

12. Ruby JD, Li Y, Luo Y, Caufield PW. Genetic characterization of the oral Actinomyces. Arch Oral Biol 2002;47:457-63.

13. Frandsen EV, Poulsen K, Kilian M. Conformation of the species Prevotella intermedia and Prevotella nigrescens. Int J Syst Bacteriol 1995;45:429-35

14. Okamoto K, Nakayama T, Kadowaki N, Abe DB, Ratnayake K. Involvement of a lysine-specific cysteine proteinase in hemoglobin adsorption and heme accumulation by Porphyromonas gingivalis. J Biol Chem 1998;273:21225-31.

15. Smalley JW, Silver J, Birss AJ, Withnall R, Titler PJ. The heme pigment of oral anaerobes Prevotella nigrescens and Prevotella intermedia is composed of iron (III) protoporphyrin IX in the monomeric form. Microbiology 2003;149:1711-8.

16. Tanaka S, Yoshida M, Murakami Y, Ogiwara T, Shoji M, Kobayashi $\mathrm{S}$, et al. The relationship of Prevotella intermedia, Prevotella nigrescens and Prevotella melaninogenica in the supragingival plaque of children, 
caries and oral malodor. J Clin Pediatr Dent 2008;32,195-9.

17. Pearce MA, Devine DA, Dixon RA, Van Steenbergen TJ. Genetic heterogeneity in Prevotella intermedia, Prevotella nigrescens, Prevotella corporis and related species isolated from oral and nonoral sites. Oral Microbiol Immunol 2000;15:89-95.

18. Saiki K, Gomi T, Konishi K. Deletion and purification studies to elucidate the structure of the Actinobacillus actinomycetemcommitans cytolethal distending toxin. J Biochem 2004;136:335-42.

19. Leung SW. Naturally occurring stains on the teeth of children. J Am Dent Assoc 1950;41:191-7.

20. Eisenberg E. Anomalies of the teeth with stains and discolorations. J Prev Dent 1974;2:16-20.

21. King EO, Ward MK, Raney DE. Two simple media for the demonstration of pyocyanin and fluorescein. J Lab Clin Med 1954;44:301-7.

22. Bussell RM, Deery $C$. Blue chromogenic dental staining in child with West syndrome. Eur Arch Paediatr Dent 2010;11:298-9.

23. Hattab FN, Qudeimat MA, Al-Rimawi HS. Dental discoloration: an overview. J Esthet Dent 1999;11:291-9.

24. Williamson NR, Fineran PC, Leeper FJ, Salmond GP. The biosynthesis and regulation of bacterial prodiginines. Nat Rev Microbiol 2006;4:887-99.

25. Hejazi A, Falkiner FR. Serratia marcescens. J Med Microbiol 1997;46:903-12.

26. Bartels HA. A note on a chromogenic microorganism isolated from an orange colored deposit adhering to teeth. Am J Orthod Oral Surg 1939; 25:795-6.

27. Kiuchi K. Floc formation in activated sludge. J Gen Appl Microbiol 1968;14:399-409.

28. Jagannadham MV, Chattopadhyay MK, Shivaji S. The major carotenoid pigment of a psychrotrophic Micrococcus roseus strain: fluorescence properties of the pigment and its binding to membranes. Biochem Biophys Res Commun 1996;220:724-8.

29. Reid JS, Beeley JA, McDonald DG. Investigations into black extrinsic tooth stain. J Dent Res 1977;56:895-9.

30. Ozmeric N, Unlu O, Mansuroğlu H. Siyah pigmente periodontal patojenlerin aile bireyleri arasındaki bulaşıcılığı. Atatürk Üniv Diş Hek Fak Derg 2001;1:37-41.

31. Van Steenbergen TJ, Bosch Tijhof CJ, Petit MD, Van der Velden U. Intrafamilial transmission and distribution of Prevotella intermedia and Prevotella nigrescens. J Periodontal Res 1997;32:345-50.

32. Wilkins EM. Clinical practice of the dental hygienist. 8th edn. Philadelphia: Lippincott William \& Wilkins; 1999. p.603-11.

33. Koch G, Petersson LG, Johnson G. Abrasive effect and fluorine uptake from polishing and prophylactic pastes. Swed Dent J 1975;68:1-7.

\section{The role of chromogenic bacteria in external tooth discoloration in children}

\begin{abstract}
Tooth discoloration can cause social and psychological problems and lead to loss of self-confidence in children. Concerns of parents and children on appearance and esthetics increase the importance of dental esthetic treatments in children. External tooth discoloration in children can be seen in both the primary and the permanent teeth. Poor oral hygiene, use of iron preparations and chromogenic bacteria are among the etiology of external tooth discoloration. Chromogenic bacteria can cause black/ brown, green, orange or blue discolorations on the tooth surfaces of children. For clinicians, most interesting external tooth discoloration in children has been the black discoloration, which is more frequently observed compared to the other types. Most of the studies also have focused on the chromogenic bacteria associated with black discolorations, and the data concerning other types of discoloration are limited. Our knowledge on the existing chromogenic bacterial mechanisms is increasing by the developing microbiological diagnostic procedures, and new species associated with discoloration are becoming recognized. Still, studies dealing with the mechanisms of the chromogenic bacteria leading to discoloration are insufficient in the accessible sources. The objective of this article is to emphasize the role of the chromogenic bacteria in external tooth discoloration in children, to review precautions that can be taken to prevent discoloration, and current treatment methods, and to contribute to the current knowledge of the clinicians on this subject.
\end{abstract}

KeYwords: Oral hygiene; primary tooth; tooth discoloration 